\title{
Folkedrab i det lange og korte perspektiv
}

Henrik Døcker

Som folkeretligt begreb har det kun 60 på bagen, men erobringstogter tusinder af år tilbage havde i virkeligheden også folkedrabskarakter

Ben Kiernan: Blood and Soil - A World History of Genocide and Extermination from Sparta to Darfur, Yale University Press, 724 sider.

Synet på krig har ændret sig meget gennem århundrederne - men der hæfter stadig en vis 'prestige' ved at vinde én. Skoleundervisning i historie drejede sig også i lang tid mest om hvem der vandt. Den australske historiker Ben Kiernan vil med sin gigantiske bog have os til at forstå, at folkedrab kan føres tusinder af år tilbage med Romerrigets puniske krige som ét af de første markante eksempler. Han øser af et imponerende stort kildemateriale, men så meget, at han næsten drukner læseren i facts og citater.

Nuvel, det er et beundringsværdigt forsøg på at give en omfattende historisk fremstilling af begrebet folkedrab, formuleret som en særlig alvorlig folkeretskrænkelse for blot 60 år siden, nærmere bestemt da FN's Generalforsamling den 9. december 1948 vedtog den internationale konvention til bekæmpelse af folkedrab. Det tilsigtede forsøg på, helt eller delvist, at udrydde en befolkningsgruppe på grund af dennes nationale, racemæssige, etniske eller religiøse tilhørsforhold var det, verden vendte sig imod, og som signatarmagterne forpligtede sig til at bekæmpe og straffe.

Folkeretskyndige jurister har splittet mange hår siden den rwandiske borgmester Jean-Paul Akayesu i 1999 som en første i retshistorien blev dømt for folkedrab ved det særlige tribunal til domfældelse af de ansvarlige for folkedrabet i Rwanda i 1995. Det har vist sig særdeles svært for anklagemyndigheden såvel ved dette tribunal som Eksjugoslavienstribunalet at bevise folkedrabs- 


\section{LITTERATUR}

hensigten, hvorfor der i mange flere tilfælde er faldet domme for drab, tortur, deportation og andre grufuldheder under den anden kategori af grove folkeretskrænkelser, kaldet forbrydelse mod menneskeheden. Retspraksis fra tribunalerne afspejler ikke, at denne kategori udløser mildere straf.

\section{Et bredere syn}

Men historikeren Kiernan anlægger et langt bredere syn på folkedrabsbegrebet end konventionen - som i øvrigt i det væsentlige skyldtes den landflygtige polske jurist Raphael Lemkin (1900-1959). Dennes stort anlagte værk Axis Rule in Occupied Europe (Washington, 1944) om Nazitysklands jødeudryddelser såvel som hans efterladte papirer vil ind imellem blive berørt i det følgende.

Kiernan lægger ud med Romerrigets tilintetgørelse af den fønikiske stat Karthago, som der måtte tre puniske krige til, før senatoren Marcus Porcius Cato fik opfyldt sit siden hen bevingede ord: Pretereo censeo Carthaginem esse delendam. Det skete år 146, da angiveligt 70.000 indbyggere blev slagtet i første omgang, idet de ikke ville efterkomme romernes krav om at forlade deres bystat og sløjfe deres religiøse riter. Det var Scipio, som fik brudt Karthagos mure, og det var ham som tog 55.000 overlevende som slaver. Mindst seks puniske byer jævnedes med jorden, og ødelæggelserne strakte sig længere ud, eftersom Rom havde sværget at udrydde alle, der havde været i ledtog med karthagerne.

Oven på dette 'horror-glimt' fra oldtiden virker det næsten beroligende, at Kiernan konstaterer, at middelalderens erobringstogter nok var brutale, men sjældent nåede ud til folkedrabskarakter.

Nok er der rædselsberetninger om, at kejser Karl den Store under en krig med sakserne halshuggede 4500 saksiske krigsfanger på én dag, men oftere skred sejrende magter til deportationer. Som Europa voksede sig stærkere udøvedes dog ind imellem enkeltstående massakrer, som i hvert fald havde folkedrabskarakter (vil jeg tillade mig at sige uden udtrykkeligt belæg hos Kiernan), fx da omkring 8000 jøder blev myrdet i otte tyske byer maj-juni 1096. Og da korsfarerne tre år senere ifølge ærkebiskoppen af Tyros tog livet af titusinder af 'vantro', her såvel muslimer som jøder.

Ordet race begyndte at dukke op i europæiske sprog i det 14. århundrede, men i begyndelsen sigtede det dog nok til det, som man i det 16. århundrede betegnede som nationalitet. Kiernans 'rædselskabinet' åbner nu døren til den spanske erobring af Sydamerika, conquistadorernes tid. Hovedkilden til spaniernes brutale fremfærd er her Bartolomé de las Casas, en munk, der en overgang var slaveejer, men som én af de få blev grebet af anger 
og udviklede sig til den fremmeste kritiker af den brutalitet, spanierne udøvede: Deres mishandling af og drab på tusinder af indianere. Ifølge Kiernan var det dog et fåtal, der direkte blev dræbt.

Men spanierne var oprørte over, at indianerne ikke kunne formås til at dyrke jorden. Og dermed tages hul på et tema, som vil vende tilbage mange gange i forfatterens beskrivelser: Kolonialisternes næsten romantiske opfattelse af dyrkning af jorden i forbindelse med udbredelse af deres i kristendommen indsvøbte ideer om den hvide races overlegenhed for ikke at sige civilisatoriske mission - en selvindbildt legitimering af uhyrlige tvangsmetoder.

Fra Columbus' første kolonisering af områder i Caraibien videre til Cortés' blodbad på indianerne i Mexico: Af den befolkning, som dér i begyndelsen af 1500-tallet skønnedes at være 12 millioner, blev 85 pct. udryddet i løbet af blot et par år.

Mange citater beretter lige ud om nedslagtningerne af mænd, kvinder og børn. Hensigten var imidlertid ikke at udrydde indianerne som sådan, snarere at befæste de spanske kolonisters magt og påtvinge befolkningen spanske, kristne normer.

Kiernans bog svækkes betydeligt ved, at han detaljeret beretter om gruopvækkende massakrer, uden at han analyserer dem i forhold til folkedrabsbegrebet som sådan. Og det meste af det er altså $i k k e$ folkedrab, når det kommer til stykket.
Få vil nok betragte Englands kolonisering af Irland som folkedrab, men det var altså en meget blodig affære det 16. århundrede igennem, begyndende med forbud mod det irske sprog (gælisk) i 1537. I løbet af ti år, ca. 1580-90, blev befolkningen reduceret med 30 pct., idet mange byer blev lagt i ruiner.

Barbariet var ikke mindre i den nye verden, i Nordamerika, hvor en traktat ligefrem fastslog, at indianerstammenavnet pequoterne skulle droppes, idet også stednavnene (naturligvis) ændredes til det velkendte, fx New London og en flod til Themsen! Af denne stamme blev 35 pct. i løbet af ét år ombragt af kolonimagten. Det lå tungt med at have fanger, og en del af disse blev simpelthen solgt.

\section{Det 20. århundredes brutalitet}

Vi når så op til det 20. århundrede og dermed - takket være en tydeligere identifikation af enkelte staters befolkningsgrupper - til et egentligt grundlag for at bedømme hvorvidt denne eller hin brutalitet, forfølgelse eller nedslagtning har karakter af folkedrab.

Tysklands sene forsøg på at opbygge et kolonirige i Afrika, nærmere betegnet i nutidens Namibia, tidligere kaldet Sydvestafrika, tog livet af mellem $5.000 \mathrm{og} 20.000$ hereroer. Mænd, kvinder og børn blev myrdet i tusindvis, men officielt blev de 'bare' fordrevet fra deres 


\section{LITTERATUR}

jordlodder. Hereroerne fik simpelthen ordre til at forlade deres traditionelle områder, mange blev skudt, deres vandhuller forgiftet.

En del eksperter opfatter ikke denne undertvingelse, så barsk og blodig den end forekom, som folkedrab, fordi Tysklands formål primært var at sikre sig en koloni på sine betingelser, men Kiernan vil gerne inkludere dette folk, så meget mere som der i 1904 udstedtes en Vernichtungsbefehl: "Herero-folket må forlade dette landområde, hvis det ikke sker, vil jeg gennemtvinge det ved hjælp af artilleri, og hver herero, bevæbnet som ubevæbnet.. vil blive skudt", hed det i en ordre fra den tyske general Lothar von Trotha. På tre år omkom 30 pct. af den indfødte befolkning svarende til ca. 10.000 mennesker om året.

\section{Folkedrab på armenierne}

Indiskutabelt - undtagen i nutidens Tyrkiet - forekommer Det Osmanniske Riges folkedrab på dettes armenske befolkningsgruppe. En beslutning fra sultanen i Istanbul om at armenierne skulle betale dobbeltskat udløste et oprør i 1894. Da det ikke umiddelbart lykkedes at undertvinge det, indsatte sultanen 12 hærbataljoner, som afbrændte i alt 25 landsbyer. Ifølge nogle kilder skulle 80.000 til 100.000 mennesker være omkommet i løbet af et års tid, mens overlevende i 550 landsbyer blev tvangsislamiseret. Da osmannerne i
1914 trådte ind i Første Verdenskrig på Tysklands side, var armeniernes skæbne på det nærmeste beseglet: Ungtyrkernes organisation, Komiteen for Samling og Fremskridt (CUP), støttede en hård kurs mod de oprørske armeniere.

Men først og fremmest blev armenierne (der udgjorde ca. fem pct. af befolkningen i Osmanner-riget) alle sendt $\mathrm{i}$ arbejdsbrigader, hvorfra mange deporteredes eller dræbtes i massakrer. Myndighederne løslod også et betydeligt antal tyrkiske kriminelle fra fængslerne og rekrutterede dem til dødspatruljer. Kiernan serverer mange citater fra osmanniske øvrighedspersoner, som åbenlyst støttede ombringelse af armeniere og også af de osmanner, som måtte hjælpe armenierne.

Tyske og britiske diplomater og andre indberettede herom til deres regeringer, men kilder henviser også til direkte beslutninger i centralkomiteen for ungtyrkernes CUP. Begrundelsen for hvad der i dag betegnes som folkedrabet på omkring 1,5 mio. armeniere i 1915 kommer Kiernan ikke meget ind på, men andre kilder peger på osmannernes frygt for at armenierne ville støtte fjenden Rusland.

Men 1917-18 lider de tsaristiske hære i Kaukasus nederlag, og osmanniske styrker trænger ind i Russisk Armenien, hvor 300.000 armeniere havde søgt tilflugt under krigen: $\mathrm{Nu}$ fortsatte ungtyrkernes blodbad på armenierne også her. Hur- 
tigt ændres magtforholdene imidlertid, verdenskrigen sluttede med tysk nederlag, og sultanen i Istanbul var mand for nu at erklære CUP's nedslagtning af armenierne 'forbrydelser mod menneskehedens love'.

To ledende ungtyrkere blev døds$\mathrm{d} ø \mathrm{mt}$ for at have organiseret massedrab, bl.a. ved at kaste armeniere ud fra både på havet. Flere andre ledende ungtyrkere blev ved en tyrkisk militærdomstol dømt in absentia. Kiernan opgiver ikke hvor mange, der modtog fængselsdomme, men antallet af retssager angives til godt en snes.

Det nutidige Tyrkiets indædte modvilje mod at erkende armenier-folkedrabet debatteres ikke af Kiernan en tyrkisk frygt for massive erstatningskrav fra armensk side menes af nogle eksperter at være den væsentligste grund.

\section{Hungerkatastrofen i Ukraine}

Blandt Europas politiske massemord indtager den hungersnød, Sovjetunionen i 1932-33 påtvang Ukraine som led i opbyggelsen af den unge sovjetstat også en betydelig plads. Mens Kiernan også her leverer striber af relevante citater, sætter han ikke skarp fokus på den diskussion, som i de sidste par år er opstået om hvorvidt denne forfærdende gigantforbrydelse også må betegnes som folkedrab. Men de tal og kendsgerninger han fremlægger, styrker troen på folkedrabshensigten.
Tvangskollektiviseringen ramte selvejerbønder i hele Sovjetunionen, men da denne type bønder var særlig talrige i det kornrige Ukraine, kom ukrainerne til at lide uforholdsmæssig hårdt. Ifølge Kiernan levede kun tre pct. af bønderne i 1928 i kollektiver, mens det to år efter var 60 pct. Den blodige modstand mod kollektivbrugene fik simpelthen millioner af bønder til at forlade deres ejendomme, samtidig med at den sovjetiske diktator Josef Stalin forhøjede påbudte kornleverancer til staten eksorbitant.

De spredte citater om at "holde godt øje med Ukraine", at "omkringrejsende ukrainere demoraliserede kollektivbrugene" eller at "det ukrainske kommunistparti var skrækkeligt [afsporet fra den rette kommunistiske kurs]" kan ikke uden videre tolkes som en klar hensigt om at tilintetgøre den ukrainske nation.

Men det står fast, at den ukrainisering, dvs. støtte til ukrainsksprogede skoler og udvikling af ukrainske bykadrer, som Stalin i 1920'erne fandt nyttig og reelt støttede, ret brat sluttede i december 1932, da det sovjetiske kommunistpartis centralkomité udlagde de voldsomme folkevandringer, dvs. de tusinder af forarmede bønder, berøvet deres korn og ejendele af barbariske byaktivister, som noget der var igangsat af Sovjetunionens fjender (bl.a. Polen). Tusinder af disse mennesker havnede så i Gulag-lejrene. Men det 


\section{LITTERATUR}

ramte såvel ukrainere som polakker og andre nationaliteter.

Her er det nødvendigt at foretage en digression til den ukrainske historiker Roman Serbyn, som gør opmærksom på, at folkedrabskonventionens 'fader', Raphael Lemkin i et uudgivet efterladt manuskript til en bog om folkedrabets historie udtrykkeligt også hertil henregner de excessive krav om ukrainernes kornafleveringer til staten, de fortvivlede forældre, som drog tiggende rundt i byerne, og de tusinder af forladte børn - hele dette mareridt, som trods Stalins forsøg på at afsondre Ukraine fra omverdenen i 1932-33 alligevel er blevet kendt og dokumenteret i udlandet.

Dette til trods har mange folkeretslærde i forskellige lande pointeret, at Sovjetunionen ikke dengang tilkendegav en klart hensigt om at eliminere den ukrainske nation eller det ukrainske folk.

På Sovjetunionens foranledning blev politiske og sociale grupper ikke nævnt i konventionen. Årsagerne var flere, men i hvert fald juristerne pegede på, at tilhørsforholdet skulle være af en vis konstans, hvis man skulle forestille sig retssager mod ansvarlige for folkedrab.

Den amerikanske jurist Davis Marcus har i en afhandling viet emnet kunstig hungersnød som politisk våben særlig opmærksomhed. Han finder, at der i det 20. århundrede foruden i Ukraine også var tale om uhyrlige politiske massemord gennem udsultning i Etiopien og Nordkorea. Den etiopiske regering var imidlertid 1983-85 i den situation, at den kunne drage nytte af en udstrakt tørke ved at begrænse forsyninger til oprørske provinser.

Ifølge Africa Watch omkom 400.000 mennesker i denne periode kun i begrænset omfang som følge af tørken, men snarere ved regeringens tilbageholdelse af nødhjælp Dette er udtrykkelig kriminaliseret i statutten for Den Internationale Straffedomstol.

Hans påstand om at Nordkoreas hungersnød også er kunstigt fremkaldt for at holde oppositionelle dele af befolkningen i ave, er betydelig sværere at underbygge i dette det mest lukkede land i verden $\mathrm{i}$ dag. Flere udenlandske hjælpeorganisationer, som ville undsætte særlig hårdt ramte dele af Nordkorea, er blevet lagt alvorlige hindringer i vejen. Noget bedre underbygget er det at sætte Etiopien i gabestokken for folkedrab, men ikke nødvendigvis alene ved udsultning. Under alle omstændigheder blev landets tidligere præsident Mengistu Haile Mariam i december 2006 af Etiopiens højesteret dødsdømt in absentia for folkedrab på Tigre- og Wollo-befolkene.

\section{Folkedrabet på jøderne}

Med den polske sociolog Zygmunt Baumans ord ville Nazitysklands 
folkedrab på seks millioner europæiske jøder overvejende i perioden 1940-45 næppe have været muligt før det 20. århundrede.

Den tyske diktator Adolf Hitler byggede videre på en udstrakt antisemitisme, der havde rodfæste langt ud over Tyskland, bl.a. i det Polen, som blev Anden Verdenskrigs første offer. Men han tog i virkeligheden et udgangspunkt helt tilbage til bystaten Sparta. Der var race og overmenneskeideer at blive inspireret af! Hos nazismen - som også flere af de kolonisator-stater, som Kiernan beskriver - skamroses de egne bønder, de er 'sande' bærere af nationen. Denne dyrkelse af landbrugerhvervet gik hånd i hånd med jødehadet.

Jøderne var imidlertid hindret i at eje fast ejendom, men måtte holde for simpelthen på grund af deres sammenhængskraft og beskyldtes i øvrigt for at være roden til alle Tysklands ulykker efter den 'skammelige' Versailles-traktat efter Første Verdenskrig. Kiernan lader uomtalt, at ingen af Det 3. Riges spidser i Nürnberg blev dømt for folkedrab, idet begrebet jo først kom til verden to år efter processen. Det var derfor det datidige til formålet konstruerede begreb forbrydelse mod menneskeheden kom til at dække alle de uhyrligheder, der ikke var dækket af begrebet krigsforbrydelser.

Mens Stalin med magt bragte kommunismen via bykadrer ud i landdistrikterne, benyttede Kinas
Mao Tsedung til dels den modsat rettede trafik, i hvert fald var det påfaldende, at Kinas kommunistiske parti i 1961 lukkede 100.000 virksomheder og tvang 10 millioner mennesker fra byerne ud i landdistrikterne.

Som i hele Kiernans bog bydes der på mange citater og mange tal, men pålideligheden af sidstnæunte kan med rette betvivles i mange tilfælde. Fejlslagne landreformer angives at have krævet omkring én mio. menneskeliv. Hvor mange menneskeliv kulturrevolutionen krævede er uhyre usikkert. Kiernan hælder til omkring én mio. menneskeliv. Han tager ikke rigtig stilling til, om Maos eksorbitante afleveringskrav til bønderne, de mange millioners død, der måske ikke var direkte tilsigtet, men resultat af kynisk, til det forbryderiske grænsende ligegyldighed med menneskeliv og en forfærdende uvidenhed om de basale livsgrundlag for bønderne, er folkedrab.

\section{Fra Rwanda til Bosnien}

Nået frem til Rwanda, Cambodia, Irak (Halabja) og Bosnien (særlig Srebrenica), er vi straks på mere sikker grund. Det virker ude af proportion så kortfattet han befatter sig med sidstnæunte (godt seks sider). Rwandas indre rivninger går helt tilbage til Tysklands kolonisering af det daværende Ruanda-Urundi for godt 100 år siden, bestandig favori- 


\section{LITTERATUR}

serende mindretallet af tutsier, noget den påfølgende belgiske kolonimagt i 1916 fortsatte. Da de som Rwanda og Burundi blev selvstændige i 1954, var de begge forsynet med et flertal af hutuer og et mindretal af tusier, som sad på magten. Men begge folkegrupper taler samme sprog og har samme religion. Kiernan dvæler ikke ved den minimale FN-styrke, som sendtes til Rwanda i 1990'erne, og i det hele taget om verdensorganisationens svigt, hvorved folkedrabet på ca. én million (tutsier og moderate hutuer) kunne gennemføres.

Pol Pots magtovertagelse af Cambodia, uddrivelsen af bybefolkninger til landdistrikterne førte i løbet af årene 1975-79 til omkring 1,7 mio. menneskers død, mange sultede ihjel, mange blev henrettet, og atter andre døde som følge af ubehandlede sygdomme. Som under Stalins tvangskollektiviseringer, hvor ordet kulak fra at betyde selevejerbonde og siden 'storbonde' med tiden kendetegnede alt og alle, der ikke fuldt og helt sluttede op bag kollektiviseringerne, blev alle, der ikke fuldt tilsluttede sig Cambodia-kommunistpartiets linje, kaldt 'forrædere'.

Kiernan ofrer det ingen linjer, at Pol Pots Røde Khmerer ikke lod deres politiske massemord gå ud over nogen nærmere defineret gruppe (national, etnisk, racemæs- sig eller religiøs), således som folkedrabskonventionen fordrer. Hvis der var en ledetråd til de cambodianere, der især måtte lade livet, var det at de var veluddannede. Vanskelighederne med et retsopgør (det planlagte cambodiansk-internationale tribunal) efter uhyrlighederne lades aldeles uomtalt.

Kiernans store 'eksposé' har som tidligere antydet - sin force i sine mange citater til at afspejle en form for virkelighed i en mangfoldighed af blodig undertrykkelse i stor skala, det være sig i forbindelse med regulær krig eller som led i en manifest undertrykkelse af bestemte folkegrupper (folkedrabskonventionen betoner udtrykkeligt, at den befatter sig med folkedrab såvel i fred som krig).

Hans interesse for nærmere at analysere de mange situationer $\mathrm{i}$ forhold til Raphael Lemkins folkedrabsdefinition kan ligge på et meget lille sted. Hans lyst til at give en egentlig vurdering af dem i forhold til hinanden, til i pædagogisk forstand at anskueliggøre dem, er ikke til stede. Så uanset den store beundring, man må have for det enorme antal facts, Kiernan har studeret sig til, lever det store værk ikke op til den forventning, en videbegærlig læser må have. Det er en skam.

Henrik Døcker er journalist og forfatter. 